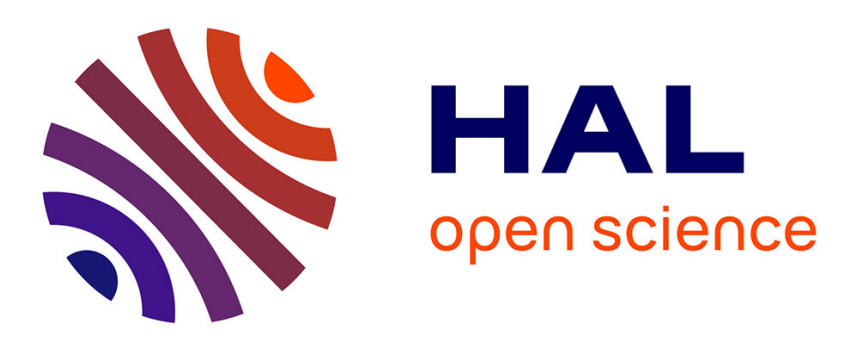

\title{
Unconstrained Nonlinear Optimization of a Distributed SWE Model Using Modis and In Situ Measurements Over the French Alps
}

Gabriel Vasile, Adrian Tudoroiu, Frederic Gottardi, Joel Gailhard, Alexandre Girard, Guy d'Urso

\section{To cite this version:}

Gabriel Vasile, Adrian Tudoroiu, Frederic Gottardi, Joel Gailhard, Alexandre Girard, et al.. Unconstrained Nonlinear Optimization of a Distributed SWE Model Using Modis and In Situ Measurements Over the French Alps. IGARSS 2013 - IEEE International Geoscience and Remote Sensing Symposium, Jul 2013, Melbourne, Australia. pp.1170-1173. hal-00972653

\section{HAL Id: hal-00972653 https://hal.science/hal-00972653}

Submitted on 3 Apr 2014

HAL is a multi-disciplinary open access archive for the deposit and dissemination of scientific research documents, whether they are published or not. The documents may come from teaching and research institutions in France or abroad, or from public or private research centers.
L'archive ouverte pluridisciplinaire HAL, est destinée au dépôt et à la diffusion de documents scientifiques de niveau recherche, publiés ou non, émanant des établissements d'enseignement et de recherche français ou étrangers, des laboratoires publics ou privés. 


\title{
UNCONSTRAINED NONLINEAR OPTIMIZATION OF A DISTRIBUTED SWE MODEL USING MODIS AND IN SITU MEASUREMENTS OVER THE FRENCH ALPS
}

\author{
Gabriel VASILE ${ }^{I}$, Adrian TUDOROIU ${ }^{1}$, Frédéric GOTTARDI ${ }^{2}$, Joël GAILHARD ${ }^{2}$, \\ Alexandre GIRARD ${ }^{3}$ and Guy d'URSO \\ 1: GIPSA-lab, CNRS / Grenoble INP, 961 rue de la Houille Blanche, BP 46, \\ F-38402 GRENOBLE Cedex, France \\ gabriel.vasile@gipsa-lab.grenoble-inp.fr \\ 2: Electricity of France, EDF \\ DTG DMM, Grenoble, France \\ frederic.gottardi@edf.fr \\ 3: Electricity of France, EDF \\ R\&D STEP, Chatou, France \\ alexandre.girard@edf.fr
}

\begin{abstract}
In this paper we propose the optimization of the snow submodel of MORDOR using MODIS and in situ measurements for the case study of the Serre-Ponçon reservoir (one of the largest artificial lakes in Western Europe) on the Durance River in the French Alps. We consider the problem of optimizing the snow model as an unconstrained nonlinear optimization problem.
\end{abstract}

Index Terms - Snow, optimization, MODIS

\section{INTRODUCTION}

Snowpack estimation in mountainous regions is important for hydroelectric power supply since it allows to anticipate the water resources available during spring snowmelt and thus to optimize filling reservoirs. To achieve this estimate of the snowmelt contribution, EDF (the main French hydropower company) uses both hydrological modeling (MORDOR model [1]) and local in situ measurements. In this paper we propose the optimization of the snow submodel of MORDOR using MODIS and in situ measurements for the case study of the Serre-Ponçon reservoir (one of the largest artificial lakes in Western Europe) on the Durance River in the French Alps. The area of interest is delimited by the green rectangle from Fig. 1- (b). The water resources located inside the watershed limit in red are collected to the Serre-Ponçon reservoir located Fig. 1-(a).

Using 36 meteorological stations operated by EDF in the area of interest, the MORDOR forecasting model currently provides the snow water equivalent (SWE) used to evaluate the potential intakes to the reservoir and to optimize the operation of the Serre-Ponçon dam. Over one year, the snow water equivalent is analyzed in two phases: accumulation (SWE slowly increasing) and melting (SWE decreasing fast).

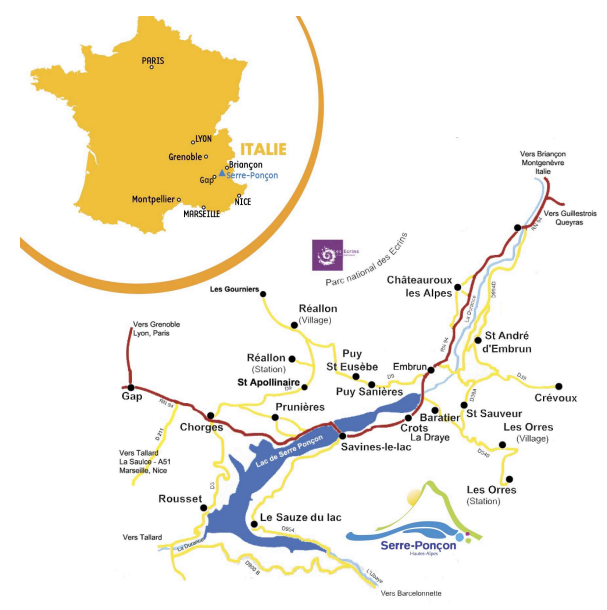

(a) 


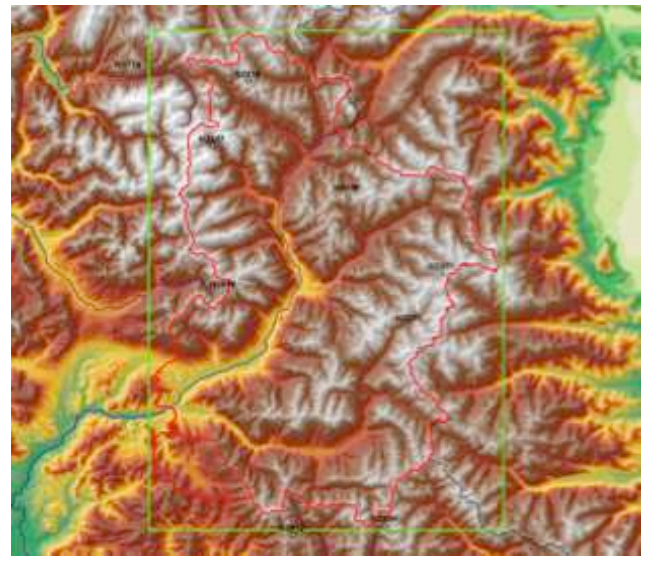

(b)

Fig. 1: (a) the Serre-Ponçon dam, France, (b) the area of interest.

Using 36 meteorological stations operated by EDF in the area of interest, the MORDOR forecasting model currently provides the snow water equivalent (SWE) used to evaluate the potential intakes to the reservoir and to optimize the operation of the Serre-Ponçon dam. Over one year, the snow water equivalent is analyzed in two phases: accumulation (SWE slowly increasing) and melting (SWE decreasing fast).

\section{DISTRIBUTED SWE MODEL OPTIMIZATION}

After kriging [2] the 36 in situ measures (temperature and precipitation), this physical model is anticipating the amount of water that is contained in the snow pack over one season [3]. The proposed optimization is carried out by comparing the MORDOR model with the SWE data measured on the terrain by remotely controlled cosmic-ray snow gauges (4 stations in the basin) [4], and also with binary snow maps derived from MODIS images [5]. We shall consider the problem of optimizing the snow model as an unconstrained nonlinear optimization problem. The MORDOR model will be described as a nonlinear function of two parameters that needs to be optimized: $\mathbf{k}_{\mathbf{f}}$ (the melting coefficient) and $\mathbf{c}_{\mathbf{p}}$ (the accumulation coefficient). Different optimization scenarios are studied:

1. according to the snow phase: accumulation or melting;

2. according to the parameter to be optimized: $\mathbf{c}_{\mathbf{p}}$ or $\mathbf{k}_{\mathbf{f}}$;

3. according to the MSE minimization method: Nelder-Mead, pattern search, genetic algorithms and simulated annealing.

To evaluate the difference between the data provided by the snow model and the data collected from the measurement stations, we use the standard Mean Squared Error (MSE) measure. Let $\mathbf{g}\left(\mathbf{c}_{\mathbf{p}}, \mathbf{k}_{\mathbf{f}}, \mathbf{t}\right)$ be the SWE from MORDOR and let $\mathbf{h}(\mathbf{t})$ be the measured SWE over one year. Then we can write the following equation:

$$
\left[c_{p}, k_{f}\right]=f\left(\operatorname{MSE}\left\{g\left(c_{p}, k_{f}, t\right), h(t)\right\},\left[c_{p_{-} \text {init }}, k_{f_{-} \text {init }}\right]\right) \text {. }
$$

The proposed optimization $\mathbf{f}$ starts at the point $\mathbf{x}_{\mathbf{0}}=\left[\mathbf{c}_{\mathbf{p}_{-} \text {init }}, \mathbf{k}_{\mathbf{f}_{\_} \text {init }}\right]$ and finds the global minimum $\mathbf{x}=\left[\mathbf{c}_{\mathrm{p}}, \mathbf{k}_{\mathbf{f}}\right]$ for the MSE. Optimization strategies tested in this paper are:

- fmin search - Nelder-Mead simplex function minimization [6];

- pattern search - constructs a sequence of iterations that converge to an optimal solution [7];

- genetic algorithm - based on a natural selection process that mimics biological evolution [8];

- simulated annealing - probabilistic search algorithm that seeks to improve the current minim by slowly reducing the extent of the search [9].

We can split the optimization problem in more phases (intervals):

1. first interval - phase of snow accumulation and melting (the whole year $\left[\mathbf{D}_{\mathbf{s}}, \mathbf{D}_{\mathbf{e}}\right]$ ),

2. second interval - the phase of snow accumulation $\left[\mathbf{D}_{\mathrm{s}}, \mathbf{D}_{\mathrm{m}}\right]$,

3. third interval - the phase of snow melting $\left[\mathbf{D}_{\mathbf{m}}, \mathbf{D}_{\mathbf{e}}\right]$. To automatically detect $\mathbf{D}_{\mathbf{s}}$ (start day), $\mathbf{D}_{\mathbf{m}}$ (middle day) and $\mathbf{D}_{\mathbf{e}}$ (end day), we use gradient-oriented thresholding of the measured data.

\section{MODIS MAP OPTIMIZATION OF THE SNOW MODEL}

To compare the snow model SWE data with the data measured by MODIS (Fig. 2), the MORDOR output data must be firstly binarized. One way to do this is by choosing a specific threshold value T: all SWE values less than $\mathbf{T}$ are labeled to " $\mathbf{0}$ " and the values greater than $\mathbf{T}$ to " 1 ". Unfortunately this method does not allow conventional optimization since the function $\mathbf{f}$ is not continuous. To obtain this, we propose to apply continuous binarization by using the tangent hyperbolic function:

$$
\operatorname{bin}=\frac{\tanh \left(\frac{h_{s}}{\sigma_{b}}\right)+1}{2},
$$

where $\boldsymbol{\sigma}_{\mathbf{b}}$ is a parameter depending of the incertitude of our maps and $\mathbf{h}_{\mathbf{s}}$ is the height of the snow.

To find the best binary fit of the MORDOR data, we must find the best value for $\boldsymbol{\sigma}_{\mathbf{b}}$ by optimizing the snow model with the data from the MODIS maps and also with data from the in situ measurements:

$$
\left[\sigma_{b}\right]=f\left(\operatorname{MSE}\left(\operatorname{bin}\left[g\left(c_{p}, k_{f}, t\right), \sigma_{b}\right] \cdot g\left(c_{p}, k_{f}, t\right), m(t) \cdot h(t)\right), \sigma_{\text {init }}\right)
$$




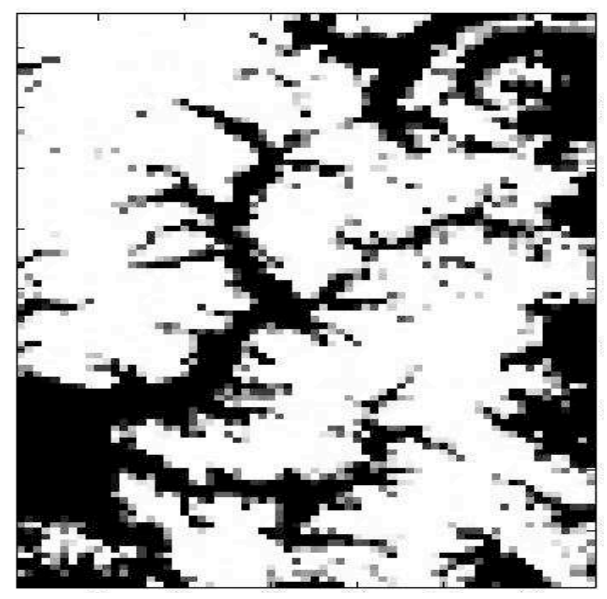

(a)

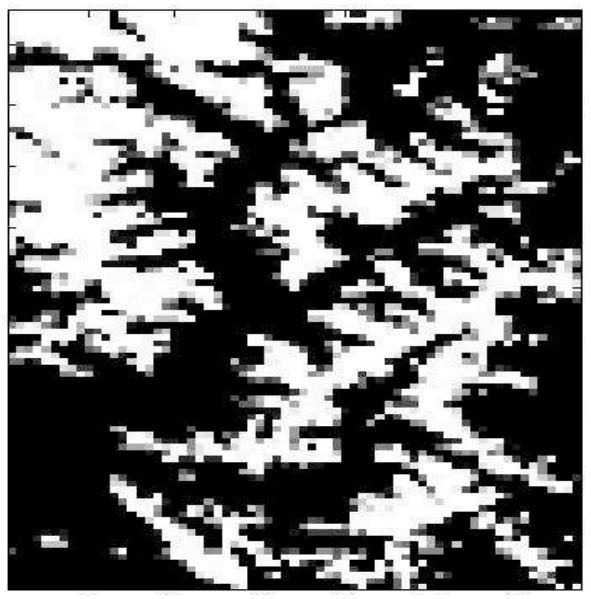

(b)

Fig. 2: MODIS map for (a) 03/07/2000 and (b)

$$
\text { 03/16/2000. }
$$

where $\mathbf{m}$ is data from MODIS map. Using this new value for the binarization function we can optimize the snow model as in the previous section:

$$
\left[c_{p}, k_{f}\right]=f\left(\operatorname{MSE}\left(\operatorname{bin}\left[g\left(c_{p}, k_{f}, t\right), \sigma_{b}\right] \cdot g\left(c_{p}, k_{f}, t\right), m(t) \cdot h(t)\right), c_{p_{-} \text {init }}, k_{f_{-} \text {init }}\right)
$$

\section{EXPERIMENTAL RESULTS}

In this section, we present some results derived for only one station (6415). In the proposed experiment, the results from four stations were considered: station number 6415,6460 , 6470 and 6510. The obtained experimental results, illustrated in Fig. 3, indicate a good matching with respect to in situ SWE measures on each ground station.

Finally, qualitative performance assessment is proposed in table 1 .

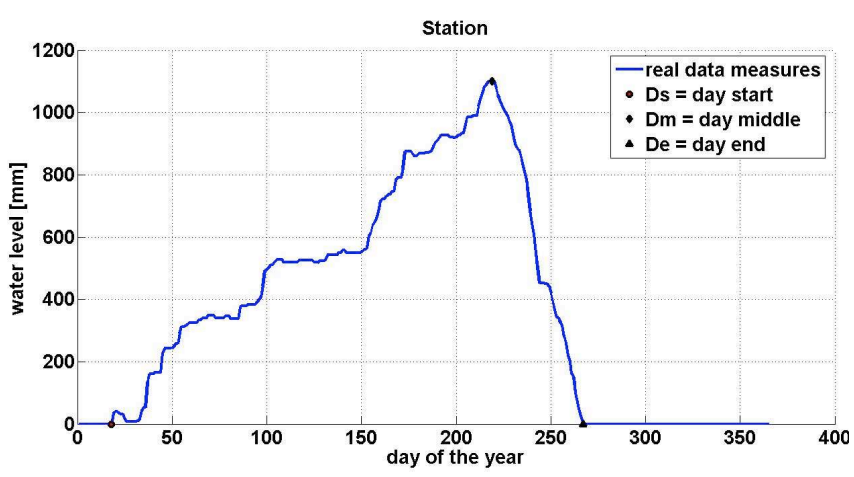

(a)

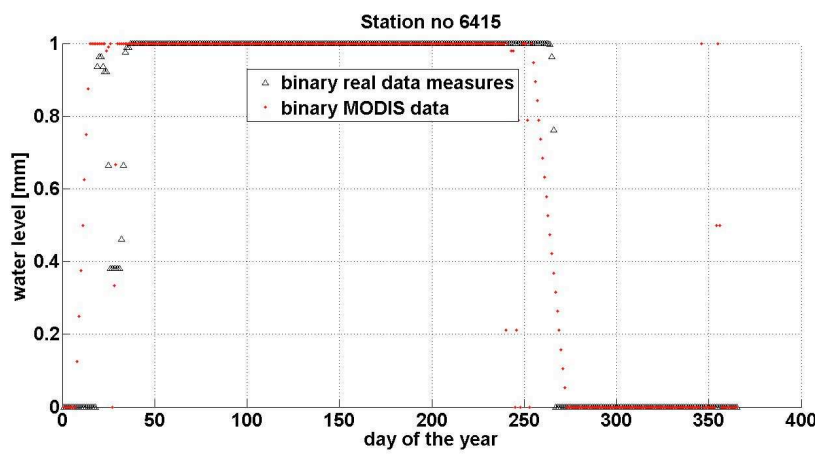

(b)

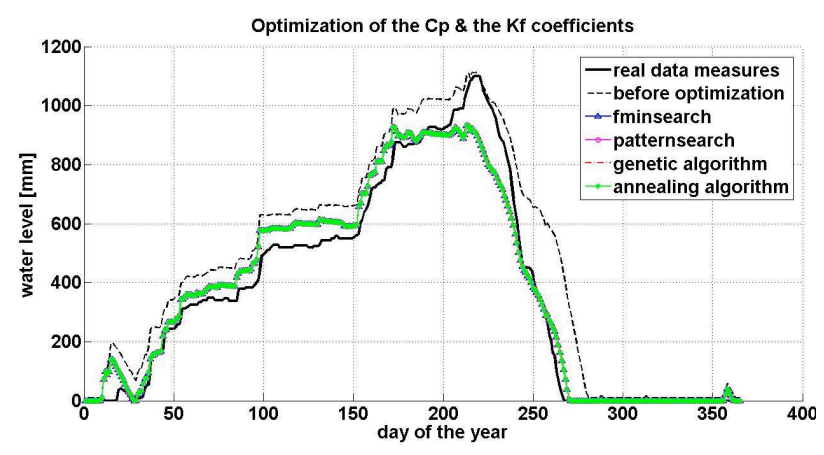

(c)

Fig. 3: (a), $D_{s}, D_{m}$ and $D_{e}$ computed for one station,

(b) binary data from real measures compared to binary data from MODIS maps, (c) Optimization of the $c_{p}$ and the $k_{f}$ coefficients of the MORDOR model for the snow accumulation phase. 
TABLE I. OPTIMIZATION FOR THE FIRST INTERVAL 1-365 DAY

\begin{tabular}{|c|c|c|c|c|}
\hline \multicolumn{5}{|c|}{ 1-365 day } \\
\hline $\begin{array}{c}\text { Optimization } \\
\text { Algorithm } \\
\end{array}$ & cpoptim & kfoptim & time & MSE \\
\hline \multicolumn{5}{|c|}{ optimize $C p$} \\
\hline $\begin{array}{l}\text { before } \\
\text { optimization }\end{array}$ & 1.300 & 3.000 & 0.2 & $7.03 \mathrm{E}+03$ \\
\hline fmin search & 1.280 & 3.000 & 6.4 & $6.88220 \mathrm{E}+03$ \\
\hline pattern search & 1.280 & 3.000 & 19.0 & $6.88220 \mathrm{E}+03$ \\
\hline genetic algorithm & 1.281 & 3.000 & 263.0 & $6.88340 \mathrm{E}+03$ \\
\hline anneal. algorithm & 1.280 & 3.000 & 2795.4 & $6.88220 \mathrm{E}+03$ \\
\hline \multicolumn{5}{|c|}{ optimize $K f$} \\
\hline fmin search & 1.300 & 2.749 & 7.0 & $6.25610 \mathrm{E}+03$ \\
\hline pattern search & 1.300 & 2.749 & 15.8 & $6.25610 \mathrm{E}+03$ \\
\hline genetic algorithm & 1.300 & 2.745 & 260.8 & $6.25630 \mathrm{E}+03$ \\
\hline $\begin{array}{l}\text { annealing } \\
\text { algorithm }\end{array}$ & 1.300 & 1.940 & 647.5 & $1.78110 \mathrm{E}+04$ \\
\hline \multicolumn{5}{|c|}{ optimize Cp \& Kf } \\
\hline fmin search & 1.190 & 2.326 & 16.0 & $4.09820 \mathrm{E}+03$ \\
\hline pattern search & 1.190 & 2.326 & 48.4 & $4.09820 \mathrm{E}+03$ \\
\hline genetic algorithm & 1.197 & 2.331 & 260.5 & $4.11160 \mathrm{E}+03$ \\
\hline $\begin{array}{l}\text { annealing } \\
\text { algorithm }\end{array}$ & 1.190 & 2.326 & 3895.6 & $4.09820 \mathrm{E}+03$ \\
\hline
\end{tabular}

\section{CONCLUSIONS}

The optimization of the snow sub-model of MORDOR using MODIS and in situ measurements was performed for the case study of the Serre-Ponçon reservoir (one of the largest artificial lakes in Western Europe) on the Durance River in the French Alps. The problem of optimizing the snow model was treated as an unconstrained nonlinear optimization problem. Several optimization strategies were investigated.

\section{ACKNOWLEDGEMENT}

This work was supported by the French National R\&D Program TSEN-X PEPS UJF-CNRS 2011.

\section{REFERENCES}

[1] R. Garçon, "Prévision opérationnelle des apports de la Durance à Serre-Ponçon à l'aide du modèle MORDOR" (in French), La Houille Blanche International Water Journal, vol. 5, pp. 71-76, 1996.
[2] P. Goovaerts, "Geostatistical approaches for incorporating elevation into the spatial interpolation of rainfall", Journal of Hydrology, vol. 228, no. 1-2, pp. 113129, 2000.

[3] F. Gottardi, J. Gailhard, "Quantitative estimation of precipitation over the French mountainous areas using snow measurements and weather patterns approach". Geophysical Research Abstracts, vol. 11, EGU2009-9718, EGU General Assembly, 2009.

[4] E. Paquet, M.T. Laval, "Operation feedback and prospects of EDF cosmic-ray snow sensors" (in French), $L a$ Houille Blanche International Water Journal, vol. 2, pp. 113-119, 2006.

[5] A.G. Klein, J. Stroeve, "Development and validation of a snow albedo algorithm for the MODIS instrument", Annals of Glaciology, vol. 34 pp. 45-52, 2002.

[6] D.M. Olsson, L.S. Nelson, “The Nelder-Mead simplex procedure for function minimization", Technometrics, vol. 17, no. 1 , pp. 45-5, 1975.

[7] A. Charles, J.E. Dennis, "Analysis of generalized pattern searches", SIAM Journal on Optimization, vol. 13, no. 3, pp. 889-903, 2003.

[8] Z. Michalewicz, "Genetic algorithms, numerical optimization and constraints", Proceedings of the 6th International Conference on Genetic Algorithms, Pittsburgh, USA, pp. 151-158, 1995.

[9] S. Kirkpatrick, C.D. Gelatt, M.P. Vecchi, "Optimization by simulated annealing”, Science, New Series, vol. 220, no. 4598, pp. 671-680, 1983. 